\title{
The maintenance of females among hermaphrodites: the importance of nuclear-cytoplasmic interactions
}

\author{
Denis Couvet, \\ Francoise Bonnemaison \\ and Pierre-Henri Gouyon*
}

Centre Emberger, CNRS, Route de Mende, BP 5051, 34033 Montpellier Cedex, France.

Female plants of Thymus vulgaris produce more seeds than hermaphrodites but their frequency in a population is not determined by the magnitude of this advantage. Instead, the proximity of the population to equilibrium determines the frequency of females: the further from equilibrium, the higher the frequency of females. This trend is due to founder effects occurring among cytoplasmic and nuclear genes determining male sterility. A review of literature supports the conclusions that male sterility in higher plants has a nuclear-cytoplasmic inheritance, that the frequency of female plants is often not at eqailibrium, and that populations far from equilibrium (young and/or disturbed) have higher frequencies of females.

\section{INTRODUCTION}

Gynodioecy is the occurrence in an interbreeding population of both female (male-sterile) and hermaphrodite plants. The maintenance of this polymorphism has not been explained clearly. Assuming no difference in survival between sexes and a higher production of seeds by females, Lewis (1941) considered the two extreme situations of complete nuclear control of male sterility and purely cytoplasmic determination. For nuclear monogenic male sterility, he argued that the frequency of females at equilibrium $(p)$ depends only on the value of the relative fertility of the females $(f)$ where:

$$
p=(f-2) /(2 f-2) .
$$

Thus, the fertility of the females must be more than twice that of the hermaphrodites, and their frequency cannot exceed 50 per cent.

For purely cytoplasmic inheritance of male sterility, Lewis (1941) showed (as revised by Lloyd, 1976) that the cytoplasmic polymorphism is maintained only by frequency-dependent selection. This can be explained by a decrease in the efficiency of pollination of the females when the producers of pollen (i.e., hermaphrodites) are rare. The hermaphrodites will avoid this decrease if

\footnotetext{
* and Institut National Agronomique, 16 rue Claude Bernard,
} 75231 Paris Cedex 05, France. self-pollination is common, or if they are in clusters.

Experimental data generally do not support the conditions of the model for nuclear inheritance suggested by Lewis (1941): frequency of females is often higher than expected in formula (1) (Lloyd, 1976 fig. 1; Webb, 1981 fig. 1), the relative fertility of females can be lower than 2 (Vaarama and Jaaskelainen, 1967; Krohne et al., 1980; Horovitz and Beiles, 1980; Uno 1982), or the frequency of females greater than 50 per cent as in Plantago lanceolata (Baker, 1963), Armeria maritima (Baker, 1966) and in Thymus vulgaris (Dommee et al., 1978).

Because of these difficulties with a purely nuclear explanation of male sterility, authors have attempted to show cytoplasmic inheritance. But hermaphrodites have often been found among the progeny of females (or females among progeny of hermaphrodites). The cytoplasmic model has therefore been rejected as it predicts no segregation. However, in the case of a nuclear-cytoplasmic inheritance, such results are not unexpected. Nevertheless, nuclear models were further examined, to the neglect of cytoplasmic models. The study of Ross and Shaw (1971) on digenic inheritance of male sterility, or the model of Charnov et al. (1976) based on game theory, both support the original conclusions of Lewis (1941), and so cannot account for experimental data. For 
self-compatible species, heterosis may explain the maintenance of females (e.g., Valdeyron et al., 1973). However, if the relative fertility of females takes into account heterosis, the model is the same as that of Lewis (1941), as pointed out by Lloyd (1976). Other hypotheses not involving cytoplasm have been suggested, which could explain the above discrepancies, namely, differential survival of the two sexual forms (Lloyd, 1974) and overdominance on male sterility loci (e.g. Ross, 1978). The experimental data, however, do not support these hypotheses (but see van Damme and van Delden, 1984 for differences in survival).

The two best known examples of putative nuclear inheritance of male sterility, in Origanum vulgare L. (Lewis and Crowe, 1956) and in Plantago lanceolata L. (Ross, 1969) have now been shown to be nuclear-cytoplasmic (Kheyr Pour, 1980; van Damme, 1983). The original studies and conclusions were based on a very small number of plants: five plants for $O$. vulgare (Lewis and Crowe, 1956) and four plants for $P$. lanceolata (Ross, 1969). A more recent putative example of nuclear inheritance of male sterility, in Silene vulgaris, was based on a study of only three plants (Horovitz and Dulberger, 1983). It seems very likely that a more complete study would show this system also to be nuclear-cytoplasmic. The only cases where cytoplasmic effects are probably not involved are for species which are functionally dioecious, since hermaphrodites produce almost no seeds, e.g., Ficus carica (Valdeyron and Lloyd, 1979) or Asparagus acuticufolius (Valdeyron et al., 1973). As would be predicted by formula (1) (see above), the frequency of females is nearly 50 per cent in these species.

Because purely cytoplasmic or nuclear inheritance of male sterility has been rejected in all studies involving large numbers of plants, theoretical models of nuclear-cytoplasmic inheritance of male sterility have been developed (e.g., Gouyon and Couvet, 1985). These models assume that each sterile cytoplasm has corresponding nuclear genes which restore the male fertility of the cytoplasm. The nuclear genes are called "restorers", and their alleles which do not restore "maintainers". When there is no maintainer the cytoplasm must be normal in that it is completely restored (i.e., male sterility is never produced). Nuclear-cytoplasmic polymorphism implies at least two different cytoplasms. Nuclear-cytoplasmic theory accounts for the experimental data, including frequencies of females higher than 50 per cent or a relative fertility of females lower than 2 (Delannay et al., 1981; Charlesworth, 1981).
We examine in this paper the ecological and genetical factors that determine the frequency of females in the gynodioecious species Thymus vulgaris L., where nuclear-cytoplasmic inheritance of male-sterility has been shown (Dommee, 1973).

\section{MATERIAL AND METHODS}

The study was carried out at four sites, located $25 \mathrm{~km}$ north of Montpellier (France). Each site is a rectangle, $1.2 \mathrm{~m}$ wide. The length of this rectangle was determined such that approximately 100 plants were in it. Environmental conditions and population features were recorded (table 1). The sexual morph and number of seeds produced were recorded for each plant, at all four sites in 1978, and only at site 2 in 1982.

All the seeds (up to a maximum of 100), produced by every plant, were sown in the greenhouse. The germination rate, survivorship rate (from germination to 2-years of age) and sexual type of the progenies were recorded.

Segregation ratios, defined as the frequency of female progeny, were computed for females and hermaphrodites in each population. A binomial distribution of sexual types was assumed to compute confidence intervals for these estimates.

\section{RESULTS}

Relative fertility of females, measured as number of germinating seeds produced by females compared to hermaphrodites, is significantly greater than 1 , except in population 3 (table 1). The survivorship rate of progeny from females and hermaphrodites is not different (table 1).

There is no correlation between the relative fertility of females (measured) and the frequency of females in the population. The population where females show the highest relative fertility has a medium female frequency (table 1).

Frequencies of females in progenies of females (45 to 79 per cent) and progenies of hermaphrodites ( 3 to 40 per cent) are both significantly correlated with the frequency of females in the population of the parents (Kendall's rank correlation test $p<0 \cdot 05$, table 1$)$.

Relative fertility of females and segregation ratios measured for population 2 were consistent in 1978 and 1982 (table 1), despite clear-cut differences in life history traits of progenies: the number of germinating seeds produced is 4 times greater in 1978 than in 1982 and the inverse is true for survivorship rate of progeny (table 1). 
Table 1 Reproductive system of thyme in four populations. Standard-errors are in brackets. Population 2 was observed on 1978 and 1982 , the other populations only on 1978. Relative fertility of females is computed as the number of germinating seeds produced by females versus hermaphrodites ( $H$ : hermaphrodites, $F$ : females)

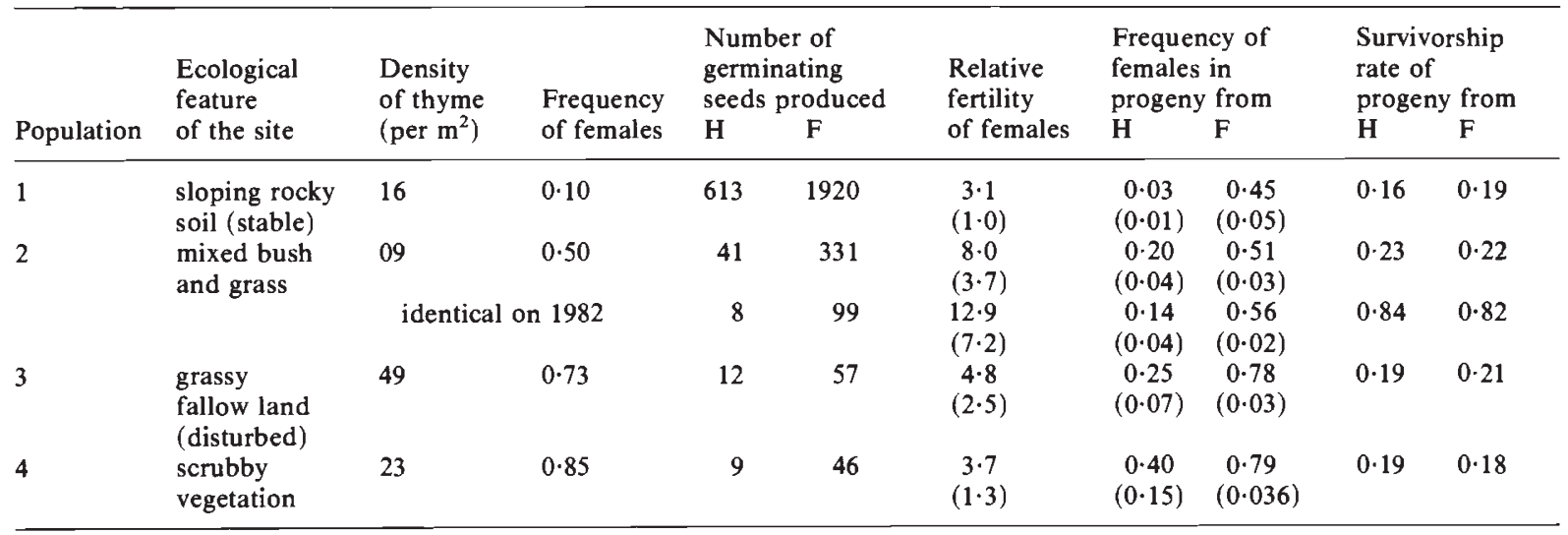

\section{DISCUSSION}

The relative fertility of females is difficult to define: it depends upon the stage of the life cycle at which the fate of progenies differs depending on maternal origin. After germination, there is no difference between progenies of females and hermaphrodites in thyme: their survivorship rate is equal (table 1), and in studies where vigour and competitive ability were also measured, no difference was found (Assouad et al., 1978; Bonnemaison et al., 1979). Therefore the relative fertility of females is accurately defined in thyme by the number of germinating seeds produced by females versus hermaphrodites. Females produce three to nine-fold more germinating seeds than hermaphrodites. A higher fertility of females has been observed in other studies of thyme (Darwin, 1877; Assouad et al., 1978), but its variations do not determine the frequency of females in a population of thyme, given the lack of correlation between these two parameters (table 1).

On the other hand, segregation ratios of malesterility are strongly related to frequency of females in the population. Segregation ratios measured on population 2 for two different years are very close, despite the number of germinating seeds produced and the survivorship rate of progeny were very different (table 1). This consistency suggests that these ratios measure the actual inheritance of malesterility of each population, and are not artefacts due to selection among sexes in the experimental conditions.

As the hypothesis of differences of viability between sexes can be rejected in thyme (Assouad et al., 1978), we built a descriptive model to see if relative fertility of females and segregation ratios can account for the frequency of females in a population. $p^{\prime}$, the frequency of females in the following generation is:

$p^{\prime}=(f \cdot p \cdot H M S+(1-p) . H M F) /(f \cdot p+1-p)$

where $p=$ the frequency of females in the population; $f=$ the relative fertility of females; $H M S=$ the frequency of females among progenies of the females of the population; $H M F=$ the frequency of females among progenies of the hermaphrodites ( $H M S$ and $H M F$ are the segregation ratios defined above).

The frequency of females expected at equilibrium can be determined using formula (2) (with $p^{\prime}=p$ ). This expected frequency is close to the frequency of females observed in each population (table 2). It is also true for the only other data we know concerning measures of segregation ratios of male sterility in a natural gynodioecious population (see table 2). Furthermore, given the differences of segregation ratios among these four populations, variations of the relative fertility of females have a marginal influence on female frequency (table 3 ). This means that the differences in segregation ratios among populations are sufficient to explain why these populations have different frequencies of females.

Interactions between cytoplasmic and nuclear genes determining male-sterility can explain the variations of segregation ratio. If females are pollinated by hermaphrodites that have not the "restorers" of their cytoplasm, male sterility has a cytoplasmic inheritance: there are only females in their progeny. The frequency of these unrestored cytoplasms increases as a result of the higher 
Table 2 Frequency of females expected at equilibrium, given measured relative fertility and segregation ratios of sexual forms (cf. text, formula 2). Data used for computation for Stellaria longipes are in Phillip (1980)

\begin{tabular}{lll}
\hline Species & $\begin{array}{l}\text { Frequency of females } \\
\text { expected }\end{array}$ & \\
\hline $\begin{array}{l}\text { Thymus vulgaris } \\
\text { Population }\end{array}$ & & \\
1 & & $0 \cdot 10$ \\
2 & 0.22 & 0.50 \\
3 & 0.48 & 0.73 \\
4 & 0.74 & 0.85 \\
Stellaria longipes & 0.75 & 0.50 \\
& 0.44 & \\
\hline
\end{tabular}

Table 3 Frequency of females expected at equilibrium, given relative fertility and segregation ratios of sexual forms (cf. text, formula 2). (*: Segregation ratios measured in 1978)

\begin{tabular}{llcc}
\hline $\begin{array}{l}\text { Segregation } \\
\text { ratios from } \\
\text { population }\end{array}$ & \multicolumn{3}{l}{$\begin{array}{l}\text { Frequency of females expected at equilibrium } \\
\text { given the relative fertility of }\end{array}$} \\
2.0 & 5.0 & 10.0 \\
\hline 1 & 0.07 & 0.21 & 0.37 \\
$2^{*}$ & 0.36 & 0.45 & 0.48 \\
3 & 0.67 & 0.74 & 0.76 \\
4 & 0.72 & 0.75 & 0.77 \\
\hline
\end{tabular}

fertility of the female individuals bearing them (they produce more seeds), and so does the frequency of females (Lewis, 1941). The frequency of females stays high as long as restorer genes of these cytoplasms are not present. When these restorer genes appear, as a result of mutation, recombination, or (more probably) migration, they are strongly favoured in these cytoplasms (because the frequency of hermaphrodites is low and it is a case of nuclear inheritance of male-sterility), thereby the frequency of females decreases. This genetical process explains why the inheritance of male-sterility and not the relative fertility of females determines the frequency of females, as suggested by our descriptive model (see above).

A question remains: when will hermaphrodites not have the restorer genes of the cytoplasm of the females? In thyme, crossing females with hermaphrodites from a different population leads to a more frequent occurence of male sterility (and sometimes only male-sterile progenies), than if hermaphrodites from the same population are used (Couvet et al., 1985). This result is interpreted as a nuclear-cytoplasmic differentiation among populations: cytoplasms are different among popula- tions and hermaphrodites have not the restorer genes for cytoplasms coming from another population. Crosses between individuals coming from different populations are likely to happen when populations are founded or disturbed, and will lead to a high frequency of females (see above). It explains why ecological studies on thyme have shown that populations with higher female frequency are younger (Dommee et al., 1983) or have undergone disturbances (Dommee et al., 1978; Gouyon et al., 1983). In this study the two populations with higher female frequency are on disturbed sites (table 1). Moreover, this founder effect explains why there is a correlation between the frequency of females and the level of polymorphism for other loci (Gouyon et al., 1986): when founded, a population is composed of a mixture of genotypes which are homogeneised, as time passes, by selection and/or drift.

The same process probably occurs in other gynodioecious species: a nuclear-cytoplasmic differentiation for male-sterility between populations has been described in Hordeum vulgare (Ahokas, 1979) and in Brassica juncea (Banga and Labana, 1985), higher female frequency in young and/or disturbed populations observed in the gynodioecious species Origanum vulgare (ElenaRossello et al., 1976; Iestwaart et al., 1984) and Silene maritima (Baker and Dalby, 1981).

\section{CONCLUSION}

Because cytoplasmic information is usually not transmitted through pollen in higher plants, a cytoplasmic information blocking androgenesis is favoured, as long as male-sterility allows a higher production of seeds (Lewis, 1941; Cosmides and Tooby, 1981; Charnov, 1982). The resulting increase in female frequency fawours nuclear genes restoring male fertility: the higher the frequency of females, the higher the selective pressure in favour of any specific nuclear gene restoring male fertility of the sterile(s) cytoplasm(s). There is a conflict of interests between nuclear and cytoplasmic genes, such that no equilibrium is possible in a population. Sterile cytoplasms are selected in founding populations (as a result of absence of their restorer genes) and nuclear restorer genes are selected in older populations (where they have reached their corresponding sterile cytoplasm). Equilibrium can exist only at the scale of a metapopulation (a metapopulation being a set of populations that interact, primarily during founding events, as defined by Gill, 1978). Models to explain 
maintenance of a nuclear-cytoplasmic polymorphism for male-sterility should therefore be devised according to a metapopulation scale (Gouyon and Couvet, 1985).

This conflict of interest between nuclear and cytoplasmic genes should have occured in every hermaphroditic species. The existence of sterile cytoplasms and corresponding nuclear restorer genes has been shown in a wide range of hermaphroditic species of higher plants (see Grun, 1976; Tables 12 and 13 for a review). Male-sterility resulting from crosses between related species or genera can be explained by a nuclear-cytoplasmic differentiation, among species in this case. However, male-sterility (with a nuclear-cytoplasmic determinism) also occurs spontaneously in hermaphroditic species (see Edwardson, 1970). We suggest that colonisation of new environments, with the founder effect described above, together with male-sterile plants producing more seeds than hermaphrodites in these new environments, would lead to higher frequencies of the initially cryptic male-sterile individuals. As a result, the hermaphroditic species could become gynodioecious. This process would explain why gynodioecious species of Fuchsia occur in marginal areas (Raven, 1979), why Armeria maritima has become gynodioecious after colonisation of the New World (Baker, 1967) and in general why gynodioecious species are more common on islands (Carlquist, 1974).

Acknowledgements We thank Janis Antonovics, David Jones, Finn Kjellberg, David Lincoln, Isabelle Olivieri, Anne Tray, Georges Valdeyron and an anonymous reviewer for helpful scientific and linguistic comments.

\section{REFERENCES}

AHOKAS, H. 1979. Cytoplasmic male-sterility in Barley. III. Maintenance of steriltiy and restoration of fertility in the msml cytoplasm. Euphytica, 28, 409-420.

ASSOUAD, M. W., DOMMEE, B., LUMARET, R. AND VALDEYRON, G. 1978. Reproductive capacities in the sexual forms of the gynodioecious species Thymus vulgaris L. Bot. J. Linnean Soc., 77, 29-39.

BAKER, A. J. M. AND DALBY, D. H. 1981. Morphological variation between some isolated populations of Silene maritima within the British isles with particular reference to inland populations on metalliferous soils. New Phytol., 84, 123138.

BAKER, H. G. 1963. Evolutionary mechanisms in pollination biology. Science, 139, 877-883.

BAKER, H. G. 1966. The evolution, functioning and breakdown of hetermorphic incompatibility systems. I. The Plumbaginaceae. Evolution, 20, 349-368.

BAKER, H. G. 1967. Support for Baker's law-as a rule. Evolution, $21,853-856$.
BANGA, S. S. AND LABANA, K. S. 1985. Male-sterility in Indian Mustard (Brassica juncea L.) IV. Genetics of MS-4. Can. J. of Gen. and Cyt., 27, 487-490.

BONNEMAISON, F., DOMMEE, B. AND JACQUARD, P. 1979. Etude experimentale de la concurrence entre formes sexuelles chez le thym, Thymus vulgaris. Oecol. Plant., 14, 85-101.

CARLQUIST, S. 1974. Island Biology. Columbia University Press, New York.

CHARLESWORTH, D. 1981. A further study of the problem of the maintenance of females in gynodioecious species. Heredity, 46, 27-39.

CHARNOV, E. L., MAYNARD-SMITH, J. AND BULL, J. J. 1976. Why be an hermaphrodite? Nature, 263, 125-126.

CHARNOV, E. L. 1982. The theory of sex allocation. Princeton University Press, New Jersey.

COSMIDES, L. M. AND TOOBY, J. 1981. Cytoplasmic inheritance and intragenomic conflict. J. Theor. Biol., 89, 83-129.

COUVET, D., GOUYON, P. H., KJELLBERG, F. AND VALDEYRON, G. 1985. La differenciation nucleo-cytoplasmique entre populations: une cause de l'existence de malesteriles dans les populations naturelles de Thym. C.R. Acad. Sci. Paris, Serie II (18), 300, 665-668.

DARWIN, C. R. 1877. The different forms of flower on plants of the same species. D. Appleton and Company, New York.

DELANNAY, X., GOUYON, P. H. AND VALDEYRON, G. 1981. Mathematical study of the evolution of gynodioecy with cytoplasmic inheritance under the effect of a nuclear restorer gene. Genetics, 99, 169-181.

DOMMEE, B. 1973. Recherches sur la genetique ecologique de Thymus Vulgaris L. Determinisme genetique et repartition ecologique des formes sexuelles. Thes. Doct. es Sc. Montpellier, France.

DOMMEE, B., ASSOUAD, M. W. AND VALDEYRON, G. 1978. Natural selection and gynodioecy in Thymus vulgaris $L$. Bot. J. Linnean Soc., 77, 17-28.

DOMMEE, B., GUILLERM, J. L. AND VALDEYRON, G. 1983. Regime de reproduction et heterozygotie des populations de thym, Thymus vulgaris $L$. dans une succession postculturale. C.R. Acad. Sci. Paris, Serie III, 296, 111-114.

EDWARDSON, J. R. 1970. Cytoplasmic male-sterility. Bot. Rev., $36,341-420$.

ELENA-ROSSELLO, J. A., KHEYR-POUR, A. AND VALDEYRON, G. 1976. La structure genetique et le regime de la fecondation chez Origanum vulgare $L$. Repartition d'un marqueur enzymatique dans deux populations naturelles. C.R. hebd. Seanc. Acad. Sci. Paris Ser. D, 283, 1587-1589.

GILL, D. E. 1978. The metapopulation ecology of the red-spotted newt, Notophtalmus viridescens (Refinesque). Ecological Monographs, 48, 145-166.

GOUYON, P. H., LUMARET, R., VALDEYRON, G. AND VERNET, P. 1983. Reproductive strategy and disturbance by man. in Ecosystems and Disturbance, Mooney, H. (ed.), SpringerVerlag.

GOUYON, P. H. AND COUVET, D. 1985. Selfish cytoplasm and adaptation: variations in the reproductive system of thyme. In Structure and Functioning of Plant Populations/2, Haeck, J. and Woldendorp J. W. (eds.), North-Holland Publ. Comp., New York.

GOUYON, P. H., VERNET, P., GUILLERM, J. L. AND VALDEYRON, G. 1986. Polymorphisms and environment: the adaptive value of the oil polymorphism in Thymus vulgaris L. Heredity, 57, 59-66.

GRUN, P. 1976. Cytoplasmic genetics and evolution. Columbia University Press, New York.

HOROVITZ, A. AND BEILES, A. 1980. Gynodioecy as a possible population strategy for increasing reproductive output. Theor. Appl. Genet., 57, 11-15. 
HOROVITZ, A. AND DUlBERGER, R. 1983. The genetic basis of gender in Silene vulgaris L. Heredity, 51, 371-376.

IESTWAART, J. H., BAREL, R. A. AND IKELAAR, M. E. 1984. Male-sterility in Origanum vulgare populations. Acta Bot. Neerl, 33, 335-345.

KHEYR-POUR, A. 1980. Nucleo-cytoplasmic polymorphism for male-sterility in Origanum vulgare L. J. Hered., 71, 253-260.

KROHNE, D. T., BAKER, I. AND BAKER, H. G. 1980. The maintenance of the gynodioecious breeding system in Plantago lanceolata L. Amer. Midl. Natur., 103, 269-279.

LEWIS, D. 1941. Male-sterility in natural populations of hermaphrodite plants. New Phytol., 40, 56-63.

LEWIS, D. AND CROWE, L. K. 1956. The genetics and evolution of gynodioecy. Evolution, 10, 115-125.

LLOYD, D. G. 1974. Theoretical sex ratios of dioecious and gynodioecious angiosperms. Heredity, 32, 11-34.

LLOYD, D. G. 1976. The transmission of genes via pollen and ovules in gynodioecious angiosperms. Theor. Pop. Biol., 9, 299-316.

PHILliP, M. 1980. Reproductive biology of Stellaria longipes Goldie as revealed by a cultivation experiment. New Phytol., 85, 557-569.

RAVEN, P. H. 1979. A survey of the reproductive biology of Onagraceae. New Zeal. J. Bot., 17, 575-593.

RosS, M. D. 1969. Digenic inheritance of male-sterility in Plantago lanceolata. Can. J. Genet. Cytol., 11, 739-744.
ROSS, M. D. AND SHAW, R. F. 1971. Maintenance of malesterility in plant populations. Heredity, 26, 1-8.

ROSS, M. D. 1978. The evolution of gynodioecy and subdioecy. Evolution, 32, 174-188.

UNO, G. E. 1982. Comparative reproductive biology of hermaphroditic and male-sterile Iris douglasiana Herb. (Iridaceae). Amer. J. Bot., 69, 818-823.

VAARAMA, A. AND JAASKELAINEN, O. 1967. Studies on gynodioecism in the Finnish populations of Geranium sylvaticum L. Annales Acad. Scientarum Fennicae Series A IV Biologica, 108, 3-39.

VALDEYRON G., DOMMEE, B. AND VALDEYRON, A. 1973. Gynodioecy: another computer simulation model. Amer. Nat., 107, 454-459.

VALDEYRON, G. AND LLOYD, D. G. 1979. Sex differences and flowering phenology in the common fig., Ficus carica $L$. Evolution, 33, 673-685.

VAN DAMME, J. M. M. 1983. Gynodioecy in Plantago lanceolata $L$. II. Inheritance of three male-sterility types. Heredity, 50, 253-273.

VAN DAMME, J. M. M. AND VAN DELDEN, w. v. 1984. Gynodioecy in Plantago lanceolata L. IV. Fitness components of sex types in different life cycle stages. Evolution, 38, 1326-1336.

WEBB, C. J. 1981. Test of a model predicting equilibrium frequencies of females in populations of gynodioecious angiosperms. Heredity, 46, 397-405. 